\title{
Growth and consumption rates of bacterivorous Antarctic naked marine amoebae
}

\author{
Daniela F. Mayes ${ }^{1}$, Andrew Rogerson ${ }^{2, *}$, Harvey Marchant ${ }^{3}$, Johanna Laybourn-Parry ${ }^{4}$ \\ 'University Marine Biological Station Millport, KA28 0EG, Scotland, United Kingdom \\ ${ }^{2}$ Department of Chemistry and Chemical Engineering, South Dakota School of Mines and Technology, Rapid City, \\ South Dakota 57701, USA \\ ${ }^{3}$ Australian Antarctic Division, Channel Highway, Kingston, Tasmania 7050, Australia \\ ${ }^{4}$ Department of Physiology and Environmental Science, University of Nottingham, Sutton Bonington Campus, Loughborough \\ LE12 5RD, United Kingdom
}

\begin{abstract}
This is the first study to consider the growth and feeding rates of naked marine amoebae at temperatures below $5^{\circ} \mathrm{C}$. Specific growth rates were calculated for 5 Antarctic isolates, Platyamoeba australis, Mayorella sp., Metachaos sp., Vannella sp., and an unidentified vahlkampfiid amoeba. Growth rates ranged between $0.08 \times 10^{-2}$ and $2.9 \times 10^{-2} \mathrm{~h}^{-1}$ corresponding to generation times of 866.2 and $23.9 \mathrm{~h}$, respectively. All isolates grew at temperatures down to $-2^{\circ} \mathrm{C}$ and showed optimal growth at $2^{\circ} \mathrm{C}$ although one species grew best at $0^{\circ} \mathrm{C}$. A direct counting method was used to estimate bacterial feeding rates of $P$. australis and the vahlkampfiid amoeba. Rates varjed as a function of prey density but were largely independent of temperature. Overall, amoebae consumed between 0.5 and 66.4 bacteria amoeba ${ }^{-1} \mathrm{~h}^{-1}$, equivalent to 0.3 and $38.0 \mathrm{pg} \mathrm{C}$ cell $\mathrm{l}^{-1} \mathrm{~h}^{-1}$ Growth efficiencies estimated for these 2 amoebae were low, typically $<2 \%$, suggesting that a maebae incur high energetic costs for life at low temperatures
\end{abstract}

KEY WORDS: Gymnamoebae Protozoa Generation times - Feeding - Growth efficiencies

\section{INTRODUCTION}

Information on the growth and feeding rates of protozoa are essential for an understanding of their role in energy transfer to higher trophic levels and on the efficiency of carbon flow, nutrient utilization and regeneration within ecosystems. Previous studies on the growth of amoebae include those of Cutler \& Crump (1927) (Hartmannella hyalina), Pace \& Frost (1952) (Chaos carolinenese), Bunt (1970) (a marine Vexillifera), Baldock \& Baker (1980) (Polychaos fasciculatum), Heal (1967) (Acanthamoeba sp.), Rogerson (1980) (Amoeba proteus) and Rogerson \& Berger (1981) (Naegleria sp.). Most recently, the growth potential of several species of marine benthic amoebae have been studied by Butler \& Rogerson (1996). All these studies have used amoebae isolated from temperate regions

\footnotetext{
- Addressee for correspondence.

E-mail: arogerso@msmailgw.sdsmt.edu
}

and experimental temperatures ranging between 5 and $37^{\circ} \mathrm{C}$. To date, nothing is known about the growth responses of Antarctic naked marine amoebae or indeed the growth rates of any marine amoebae grown below $5^{\circ} \mathrm{C}$.

Similarly, there are no data available for feeding rates of amoebae at temperatures less than $5^{\circ} \mathrm{C}$. Given this lack of information, it is difficult to make inferences about the impact of grazing protozoa in Antarctic systems where annual sea surface temperatures of coastal regions frequently range from -1.7 to $-1.9^{\circ} \mathrm{C}$ (Knox 1970). Different approaches to measuring grazing activities of temperate protozoa have been used in previous studies. These include measuring the rate of formation and disappearance of food vacuoles (Epstein et al. 1992), comparing the densities of prey in cultures with and without predators (Caron et al. 1991), radioactive tracer methods (Nygaard \& Hessen 1990), and monitoring uptake of fluorescently labeled inert particles (McManus \& Fuhrman 1986) or fluorescently 
labeled bacteria (Sherr et al. 1987). Not all of these methods are appropriate for amoebae which feed on prey attached to surfaces, hence a method based on an approach used by Butler \& Rogerson (1997) for estimating the uptake of fluorescently labeled bacteria (FLB) by temperate amoebae was used here.

It is now widely accepted that heterotrophic flagellates are important grazers of bacterial production (Sherr et al. 1983). Several recent studies have suggested that amoebae can also be numerically important in marine systems and that their activity may have important bearing on ecosystem function. For example, up to $15000 \mathrm{~cm}^{-3}$ naked amoebae have been found in benthic sediments, suggesting that production levels of amoebae within the benthic microbial food web can range between 7.6 and $15.8 \mathrm{~kJ} \mathrm{~m}^{-2} \mathrm{yr}^{-1}$ and that annual consumption of bacteria is on the order of 21.1 to $43.8 \mathrm{~kJ} \mathrm{~m}^{-2} \mathrm{yr}^{-1}$ (Butler \& Rogerson 1996).

Compared with lower latitudes, relatively little is known about microbial plankton dynamics in Antarctic marine waters. Bacterial production in spring is reported as being around $1.070 \pm 0.206 \mathrm{mg} \mathrm{C} \mathrm{m}^{-3} \mathrm{~d}^{-1}$ dropping to $0.226 \pm 0.016 \mathrm{mg} \mathrm{C} \mathrm{m}^{-3} \mathrm{~d}^{-1}$ in autumn (Kottmeier \& Sullivan 1990). These levels are significantly lower than those achieved in warmer waters. Larger Antarctic marine protozooplankton have received some attention, for example dinoflagellates (Archer et al. 1996, Bjørnsen \& Kuparinen 1991) and ciliates and heterotrophic nanoflagellates (Garrison \& Buck 1991) have been investigated. Hara et al. (1986) presented information on the abundance of amoebae in the Southern Ocean and amoebae have been observed in sea ice assemblages by Garrison \& Buck (1991). Our unpublished data shows that they can be abundant in the plankton of Antarctic coastal waters off Davis Sta-

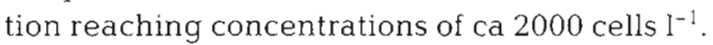

\section{MATERIALS AND METHODS}

Isolation of amoebae. Naked amoebae (gymnamoebae sensu Page 1988) were isolated from the surfaces of decaying seaweeds and/or detritus collected from shallow water adjacent to the Australian Antarctic Station of Davis between 1991 and 1993. Mixed cultures of amoebae, with attendant bacteria, were established in diluted $(50 \%)$ Erdshreiber (Merds) Seawater Medium (Page 1983). Cultures were grown in small petri dishes sealed with Parafilm to prevent moisture loss. These stock cultures were incubated at $4^{\circ} \mathrm{C}$ in the dark and examined using an inverted phase contrast microscope. Clonal cultures were established by suspending cells of a stock culture in fresh medium and pipetting off $25 \mu \mathrm{l}$ aliquots into the multi-wells of a tissue culture chamber containing Merds medium. Five clonal strains of Antarctic amoebae were isolated: Platyamoeba australis (length ca $32 \mu \mathrm{m}$ ), Mayorella sp. (length ca $36 \mu \mathrm{m}$ ), Metachaos sp. (length ca $50 \mu \mathrm{m}$ ), Vannella sp. (length ca $5 \mu \mathrm{m}$ ), and an unidentified isolate, strain 5 (length ca $5 \mu \mathrm{m}$ ). This last strain displayed eruptive locomotion and had mitochondria with discoid cristae. These are features of the vahlkampiid amoebae. The lack of any alternate flagellate stage in this isolate suggests that it may be Vahlkampfia sp.

Isolation of bacterial prey. A mixed population of bacteria was isolated from the surface of seaweed samples by plating scrapings onto the surface of Zobell agar plates which were incubated at $4^{\circ} \mathrm{C}$. Four strains of bacteria were isolated and all were found to be palatable to amoebae in preliminary growth trials. The largest isolate was chosen for subsequent experiments a Gram negative, rod-shaped bacterium with a biovolume of ca $2.6 \mu^{3}$. These large bacteria readily settled out of suspension and were available to surfaceattached grazing amoebae.

Growth rates. Bacteria were harvested from exponentially growing cultures by centrifugation. The bacterial pellet was washed in sterile seawater and the concentration of bacteria was determined by fluorescence counting after staining with the DNA specific fluorochrome DAPI. A standard curve relating turbidity to bacterial concentration was computed and used to rapidly adjust bacterial densities for the amoeba growth rate determinations. The effects of different prey densities on amoebae growth were determined for 2 of the Antarctic species, Vannella sp. and isolate 5 (the vahlkampfiid amoeba). Bacterial densities used in our experiments ranged from $0.04 \times 10^{8}$ to $3.5 \times$ $10^{8}$ cells $1^{-1}$, spanning the densities found in inshore waters adjacent to Davis Station 68 $30^{\prime} \mathrm{S}$ (Mayes unpubl.).

Over the course of the growth experiments, the number of bacteria in the experimental dishes was adjusted daily. The average number of prey settled on the base of a $6 \mathrm{~cm}$ diameter petri dish (i.e. the most meaningful measure since amoebae predominately feed on attached bacteria) was adjusted by the addition of drops of bacterial suspension. Cultures of amoebae were maintained at the experimental temperatures $\left(-2,0,2\right.$ and $\left.4^{\circ} \mathrm{C}\right)$ for several months prior to the growth experiments. For the routine cultivation of amoebae, and for the experimental treatments, diluted Merds seawater medium was used. Dense cultures of amoebae were rinsed several times in sterile seawater to remove the majority of contaminant bacteria from these mixed cultures. It was estimated that well over $95 \%$ of the bacteria were washed away by this treatment, ensuring that the growth experiments were conducted with one predominant prey bacterium. A small aliquot $(200 \mu \mathrm{l})$ of amoeba suspension was pipetted 
into the experimental petri dishes containing known densities of prey. The inoculum size (ca 100 amoeba) was not accurately quantified since Baldock \& Baker (1980) demonstrated that initial inoculum size does not affect subsequent growth rates. Five replicate dishes were prepared for each of the 4 experimental temperatures and counts of amoebae were recorded every $24 \mathrm{~h}$ using an inverted microscope. Counts were conducted over the exponential phase of growth between 4 and $15 d$, depending upon species and conditions. The number of amoebae in 20 random fields of view was recorded. The counting procedure was kept short to minimize any temperature changes during counting.

Growth rate determinations at the low temperatures used in this study were conducted at Davis Station, thus experiments on Vannella sp., Mayorella sp. and Metachaos sp. were only carried out at a prey density

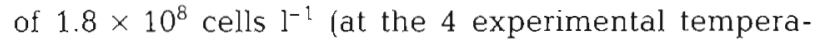
tures). This prey density was chosen because it was close to the average field density of bacteria in Antarctic coastal waters (Mayes unpubl.). Admittedly, this represented a high prey biomass $\left(4.7 \times 10^{3}{\left.\mu \mathrm{m}^{3}\right)}^{3}\right.$ since the experimental prey bacterium was large. However, amoebae probably encounter localized high prey densities in the field. It is our experience that bacteria and grazing amoebae are frequently floc-associated in the water column (Rogerson \& Laybourn-Parry 1992b) and that bacteria on these flocs are frequently large, metabolically active and located in patches (Rogerson \& Laybourn-Parry 1992c).

The growth rate constants $(\mu)$ were calculated from the slope of the expontential phase of growth; $\mu=$ $\left(\log _{\mathrm{n}} N-\log _{\mathrm{n}} N_{0}\right) /\left(t-\mathrm{t}_{0}\right)$ where $\mu$ is the specific growth rate, $N_{0}$ and $N$ are the initial and final numbers of amoebae over the time interval $\left(t-t_{0}\right)$ in h. Generation times (h) were calculated from $0.693 / \mu$.

Estimates of cell volume of amoebae were derived from measurements of maximum dimensions of 'rounded' floating cells. Appropriate formulae for the most appropriate geometric shape were applied (e.g. sphere, ovate spheroid).

Consumption rates. Direct measurements of grazing rates are preferable since they involve fewer assumptions. Butler \& Rogerson (1997) have estimated consumption rates of temperate amoebae using FLB and their method was used in the present study. The bacterium used in the growth rate experiments was stained with the fluorochrome DTAF as described by Sherr et al. (1987). Suspensions of FLB were spread evenly over the surface of MY100 agar plates (Page 1983) after being adjusted to ensure that numbers of bacteria available to grazing amoebae were identical to densities in the growth experiments.

Consumption rate determinations were conducted on 2 species of amoebae, Platyamoeba australis and isolate
5. Amoebae were grown, washed and harvested as described for the growth experiments. Drops of amoebae in sterile seawater were pipetted onto the lawn of bacteria and allowed to settle and attach for $10 \mathrm{~min}\left(=\mathrm{t}_{0}\right)$. At 10 min intervals thereafter, 1 of the inoculation sites was covered with a glass coverslip and the agar surface was examined at $\times 1000$ using phase contrast objectives to randomly locate amoebae. Once amoebae were found, blue light epifluorescence was used to determine the number of fluorescent bacteria ingested. On most occasions, at least 30 amoebae were rapidly scanned on the agar surface. However, cells were sometimes rarer ( 6 per observation period) or more abundant (up to 155). Experiments were replicated until the total number of amoebae observed per treatment ranged from 18 to 421 cells. Observations on feeding were only continued for $1 \mathrm{~h}$ since after this time some cells showed evidence of digestion of ingested bacteria; the entire cytoplasm of the cell fluoresced. Prior to the uptake rate experiments, agar plates were stored at the experimental temperatures $\left(-2,0,2\right.$ and $\left.4^{\circ} \mathrm{C}\right)$ and, between counts, plates were returned to appropriate incubators. Since the observation periods were short, and the agar acted as a 'heat sink', it is believed that temperature fluctuations during the experiments were minimal. After the experimental runs, the number of labeled and unlabeled bacteria on the agar surface was counted. The ratio of labeled to unlabeled was used to correct the uptake data for ingestion of non-FLB. It was assumed that Antarctic amoebae, like their temperate counterparts, do not select between labeled and unlabeled prey (Butler \& Rogerson 1997).

\section{RESULTS}

The effect of varying prey concentration on the growth rates of Platyamoeba australis and isolate 5 was investigated over the range $0.04 \times 10^{8}$ to $3.50 \times 10^{8}$ bacteria $l^{-1}$ (Fig. 1A-D). In the case of $P$. australis, the rate of growth tended to increase with increasing prey concentration at 0,2 and $4^{\circ} \mathrm{C}$ (data not available for $-2^{\circ} \mathrm{C}$ ) before leveling off at the 2 highest prey concentrations of $1.88 \times 10^{8}$ and $3.50 \times 10^{8}$ bacteria ${ }^{-1}$. Similarly, in the case of isolate 5 , the rates generally peaked at around $1.88 \times 10^{8}$ cells $1^{-1}$. However, across the range of prey concentrations used, few of these differences were significant except for some of the comparisons between extreme prey levels. For example, the highest prey densities at $2^{\circ} \mathrm{C}$ produced significantly higher growth rates in both species compared with the lowest prey density tested. Likewise, growth of $P$. australis at 0 and $4^{\circ} \mathrm{C}$ was greater at $3.50 \times 10^{8}$ bacterial $l^{-1}$ compared

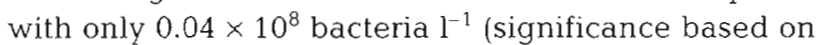
comparison of the $95 \%$ confidence intervals). 


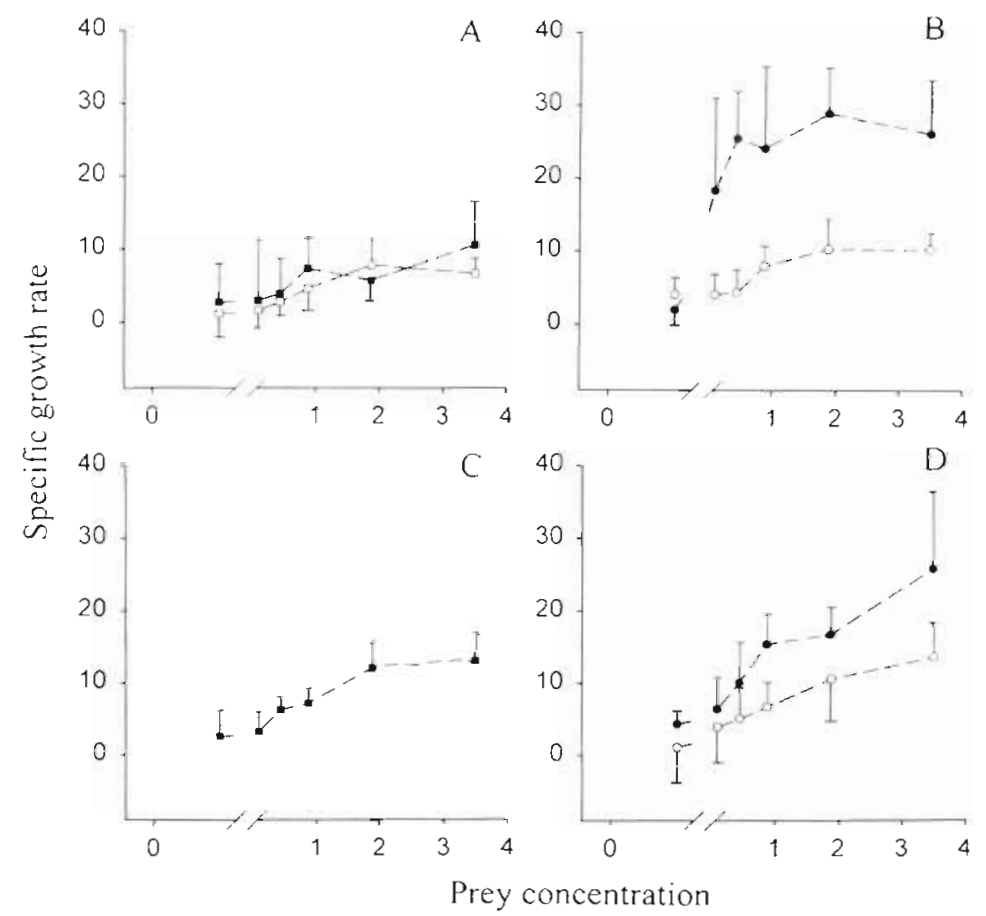

Fig. 1. Specific growth rates $\left(\mu \times 10^{3}, \mathrm{~h}^{-1}\right)$ of amoebae as a function of bacterial prey concentration $(0.04,0.09,0.44,0.90,1.88$ and 3.50 cells $\left.\times 10^{8} \mathrm{I}^{-1}\right)$. (A, B) Isolate 5 and (C, D) Platyameoba australis grown at $-2^{\circ} \mathrm{C}(\mathrm{a}), 0^{\circ} \mathrm{C}(\mathbf{a}), 2^{\circ} \mathrm{C}(\bullet)$ and $4^{\circ} \mathrm{C}(\mathrm{O})$. Means of 5 determinations with $95 \%$ confidence intervals of the slope

Subsequent experiments were conducted only at a bacterial density of $1.88 \times 10^{8} \mathrm{l}^{-1}$ since this approximated numbers in the field. It should be noted, however, that since a large bacterial isolate was used in these experiments (ca $2.6 \mu^{3}$ ) this represents a high prey biomass. This is unlikely to have introduced a significant error since the growth rates of amoebae were largely unaffected by prey concentration, especially at the higher densities (Fig. 1). It is likely that the growth rates reported represent maximal rates expected in the field under conditions when prey are plentiful. The relationship between $\log _{10}$ numbers of amoebae and time (h) was linear in every case and the fit of the regression line was significant $(p<0.05)$. The growth rate constant $\left(\mathrm{h}^{-1}\right)$ and generation times (h) calculated from the regressions are given in Table 1. Not surprisingly, the larger species, Mayorella sp. and Metachaos sp., grew substantially slower than the smaller isolates. All species grew down to $-2^{\circ} \mathrm{C}$ although this temperature produced slower growth in all 5 isolates. Above $2^{\circ} \mathrm{C}$ the growth rate decreased indicating that all these species are psychrophiles. Optimum temperature for the growth of all species was $2^{\circ} \mathrm{C}$ except for Metachaos sp. Which grew best at $0^{\circ} \mathrm{C}$. Despite these trends, growth differences observed within species were not significantly different; variation between replicates was considerable $(95 \%$ confidence intervals, Table 1) and no significant effects of temperature on growth were found.

Consumption rates of bacteria by Platyamoeba australis and isolate 5 are given in Table 2. Rates varied as a function of available prey concentration and generally increased with density. Temperature also affected prey uptake although not in a predictable manner. In the case of $P$. australis maximum ingestion rates were found at $4^{\circ} \mathrm{C}$ for the higher prey densities. At lower densities, intakes were variable and showed no clear trend, perhaps reflecting patchiness of prey on the agar test surface. Isolate 5 generally consumed more prey at the higher temperatures of 2 and $4^{\circ} \mathrm{C}$. Overall,

Table 1. Growth rate constants $\left(\mu, h^{-1}\right)$ and generation times $(G, h)$ of 5 species of Antarctic amoebae cultured at 4 temperatures at a bacterial prey density equivilent to $1.88 \times 10^{8}$ bacteria $l^{-1}$ The $95 \%$ confidence intervals of $\mu$, in parentheses, are based on pooled replicate data $(n=5)$

\begin{tabular}{|c|c|c|c|c|c|c|c|c|}
\hline \multirow{2}{*}{ Species } & \multicolumn{2}{|c|}{$-2^{\circ} \mathrm{C}$} & \multicolumn{2}{|c|}{$0^{\circ} \mathrm{C}$} & \multicolumn{2}{|c|}{$2^{\circ} \mathrm{C}$} & \multicolumn{2}{|c|}{$4^{\circ} \mathrm{C}$} \\
\hline & $\mu$ & G & $\mu$ & G & $\mu$ & G & $\mu$ & G \\
\hline Platyamoeba australis & $\begin{array}{c}0.0110 \\
(00134)\end{array}$ & 63.0 & $\begin{array}{c}0.0119 \\
(0.0193)\end{array}$ & 58.2 & $\begin{array}{c}0.0167 \\
(0.0435)\end{array}$ & 41.5 & $\begin{array}{c}0.0106 \\
(0.0396)\end{array}$ & 65.4 \\
\hline Mayorella sp. & $\begin{array}{c}0.0008 \\
(0.0028)\end{array}$ & 866.2 & $\begin{array}{c}0.0012 \\
(0.0018)\end{array}$ & 577.5 & $\begin{array}{c}0.0026 \\
(0.0010)\end{array}$ & 266.5 & $\begin{array}{c}0.0018 \\
(0.0071)\end{array}$ & 385.0 \\
\hline Metachaos sp. & $\begin{array}{c}0.0028 \\
(0.0117)\end{array}$ & 247.5 & $\begin{array}{c}0.0088 \\
(0.0134)\end{array}$ & 78.2 & $\begin{array}{c}0.0068 \\
(0.0143)\end{array}$ & 101.9 & $\begin{array}{c}0.0042 \\
(0.0099)\end{array}$ & 165.0 \\
\hline Vannella sp. & $\begin{array}{c}0.0040 \\
(0.0203)\end{array}$ & 173.3 & $\begin{array}{c}0.0044 \\
(0.0094)\end{array}$ & 157.5 & $\begin{array}{c}0.0096 \\
(0.0120)\end{array}$ & 72.2 & $\begin{array}{c}0.0054 \\
(0.0182)\end{array}$ & 128.3 \\
\hline Isolate 5 & $\begin{array}{c}0.0078 \\
(0.0226)\end{array}$ & 88.8 & $\begin{array}{c}0.0057 \\
(0.0124)\end{array}$ & 122.3 & $\begin{array}{c}0.0290 \\
(0.0465)\end{array}$ & 23.9 & $\begin{array}{c}0.0104 \\
(0.0260)\end{array}$ & 66.6 \\
\hline
\end{tabular}


regardless of prey concentration or temperature, $P$. australis consumed between 0.5 to 28.6 bacteria $\mathrm{h}^{-1}$ and isolate 5 consumed between 0.6 to 66.4 bacteria $h^{-1}$. This is equivalent to bacterial biovolume uptake rates of 1.3 to $74.4 \mu \mathrm{m}^{3} \mathrm{~h}^{-1}$ and 1.6 to $172.6 \mu \mathrm{m}^{3} \mathrm{~h}^{-1}$, respectively.

Average cell volumes, or biovolumes $\left(\mu^{3}\right)$, of the 5 amoebae showed no significant difference with prey density or temperature. Biovolumes were

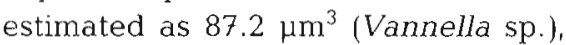

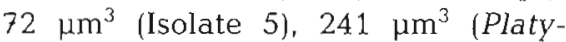
amoeba australis), $5576 \mu^{3}$ (Mayorella sp.) and $11495 \mu^{3}$ (Metachaos sp.). The data from this study and data from a study by Butler \& Rogerson (1996) for amoebae grown at $5^{\circ} \mathrm{C}$ have been plotted on a generalized relationship given by Baldock et al. (1980) for ciliates and amoebae grown between 8.5 and $20^{\circ} \mathrm{C}$. It was proposed that this regression can be used to derive the generation time of any amoeba or ciliate providing its cell volume is known and the temperature is not above the optimum for the organism. This plot (Fig. 2) shows that the data from growth determinations at temperatures of $5^{\circ} \mathrm{C}$ or less lie outside the $95 \%$ prediction limits for new individuals. This suggests that the physiological responses of amoebae growing at low temperatures are different from those grown above $8.5^{\circ} \mathrm{C}$ and that this linear relationship should be restricted to protozoa growing at temperatures above $5^{\circ} \mathrm{C}$.

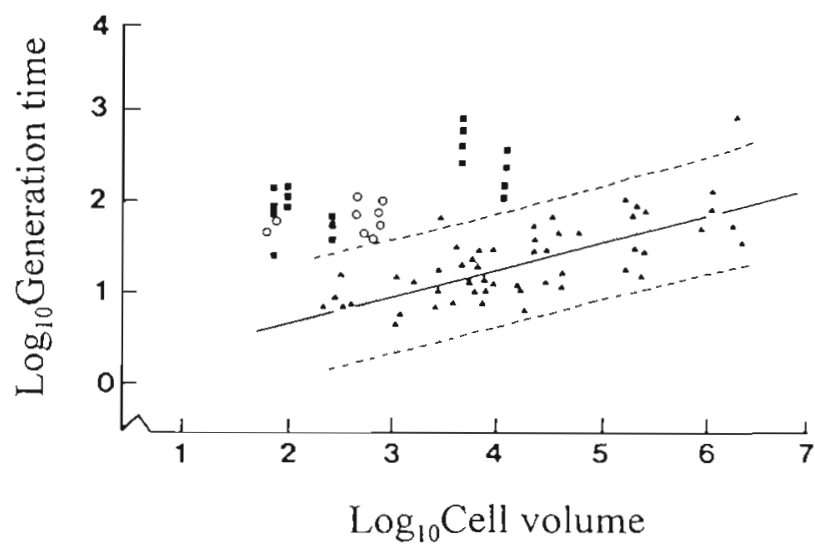

Fig. 2. Regression of $\log _{10}$ generation time $(G, h)$ against $\log _{10}$ cell volume $(\mathrm{V}, \mu \mathrm{m})$ for ciliates and amoebae at temperatures between 8.5 and $20^{\circ} \mathrm{C}$ (4) (data from Baldock et al. 1980). Dashed lines are the $95 \%$ predictions limits for new individuals. Additional points for amoebae grown at $5^{\circ} \mathrm{C}(\mathrm{O}$; Butler \& Rogerson 1996) or 4, 2, 0 and $-2^{\circ} \mathrm{C}$ (-; present study)
Growth efficiencies were estimated for Platyamoeba australis and isolate 5 grown at $1.88 \times 10^{8}$ bacteria $\mathrm{l}^{-1}$ at the 4 experimental temperatures. Production $\left({\left.\mu \mathrm{m}^{3}\right)}^{3}\right.$ over the cell cycle was approximated as 0.66 times the measured mean cell volume of the population (Butler \& Rogerson 1996). For the calculation of growth efficiencies, no attempt was made to convert biomass units to energy or carbon equivalents because there is no clear consensus on appropriate conversion factors (Butler \& Rogerson 1996). Growth efficiencies were low in all cases: $1.1,1.2,1.3$ and $1.8 \%$ for $P$. australis at $-2,0$, 2 and $4^{\circ} \mathrm{C}$, respectively. In the case of isolate 5 , efficiencies were $1.2,0.8,7.2$ and $1.6 \%$ at $-2,0,2$ and $4{ }^{\circ} \mathrm{C}$, respectively.

\section{DISCUSSION}

This is the first study to examine the growth and consumption rates of Antarctic naked amoebae. Recent work has shown that naked amoebae can, at times, be numerically abundant in the water column of coastal Antarctica reaching up to 2048 cells $\mathrm{l}^{-1}$ (Mayes unpubl.). This supports earlier work by Hara et al. (1986) who concluded that amoebae comprised a significant component of the pelagic Antarctic ecosystem.

One of the amoebae used in this study, isolate 5, had discoid, or flattened, mitochondrial cristae when examined by transmission electron microscopy (TEM.) Such vahlkampfiid amoebae are often grouped in the class Heterolobosea (sensu Page 1988). Alternatively, since amoebae in this class frequently have temporary flagellate stages, others consider them to be flagellates 
(e.g. Patterson 1994) Regardless of which classification system is adopted, all growth and consumption experiments were conducted on the amoeboid stages of this protist and no evidence of any alteration to flagellate stages was observed.

The naked amoebae isolated from Antarctic waters were all psychrophiles, according to the definition of Baross \& Morita (1978). They all had optimum growth temperatures up to $15^{\circ} \mathrm{C}$, at most, and a growth range of less than 0 to $20^{\circ} \mathrm{C}$ (the amoebae used in this study could all be grown at $20^{\circ} \mathrm{C}$ ). The temperature range used in this study was deliberately narrow since, unlike temperate protozoa, amoebae in Antarctic waters generally experience little temperature variation and the most frequently encountered water temperature is $<0^{\circ} \mathrm{C}$.

Amoebae had optimum growth rates between 0 and $2{ }^{\circ} \mathrm{C}$, suggesting that cells in situ were growing at less than their optimum rate. Indeed, at the lowest temperatures growth was slow and it is likely that most of their ingested energy was being channeled into cell maintenance rather than growth. Even during optimum growth at $2^{\circ} \mathrm{C}$, growth efficiencies were low $(0.8$ to $7.8 \%$ ). These psychrophilic amoebae are clearly exceptional among protozoa used in previous growth studies. Numerous workers have shown that protozoa in the laboratory generally increase their rate of growth with temperature up to around $20^{\circ} \mathrm{C}$ (e.g. Laybourn \& Whymant 1980 , Tobiesen 1991).

Generation times for the psychrophilic amoebae grown at $4^{\circ} \mathrm{C}$ were longer than expected $(65.4$ to 385.0 h) when compared to generation times calculated for a wide range of temperate amoebae grown at $5^{\circ} \mathrm{C}$ (32.3 to $130 h_{i}$ Butler \& Rogerson 1996). This suggests that Antarctic amoebae are fundamentally different and have undergone evolutionary adaptations to enable survival at extreme low temperatures although the exact nature of these cell changes is unknown. A number of vesicular regions within the cytoplasm of an Arctic Paramoeba sp. isolate were identified by TEM and it was suggested that these may be cryoprotein manufacturing centres (Rogerson et al. 1992). Similar regions were found in the Metachaos sp. isolate used in the present study. Although highly speculative at this time, it is possible that the relatively low growth rates are due to the energetic costs of manufacturing cryoprotectant proteins. A reduced channeling of consumed material into production is reflected in the low gross growth efficiencies calculated in this study. The values, all less than $10 \%$, are considerably lower than those estimated by Butler \& Rogerson (1996) for temperate amoebae grown at $5^{\circ} \mathrm{C}(15.1$ to $60.9 \%)$.

Relationships between growth and cell volume have been described for ciliates and amoebae (Fenchel 1968, Finlay 1977, Baldock et al. 1980) the general trend being for smaller cells to have shorter generation times than those of larger cells. The results of the present study were compared with the generalized relationship given by Baldock et al. (1980) for ciliates and amoebae (Fig, 2). Clearly the data for temperatures at and below $5^{\circ} \mathrm{C}$ lie above the projected line indicating that their generation times are markedly longer than predicted by this relationship. It is probable that this poor fit is due to the energetic costs of inhabiting cold environments. Regardless of the mechanism, it shows that care must be used when extrapolating from generalized relationships and emphasizes the need for more studies of Antarctic organisms rather than relying on extrapolations from data on temperate species.

Consumption rates were only estimated for 2 of the amoebae in this study since only these small isolates could survive in the thin film of water on the agar surface. The other small isolate, Vannella sp., was difficult to remove from culture dishes without harm. Despite the fact that only 2 species could be studied using this direct observation method, the approach was considered to be worthwhile since it is appropriate for amoebae which feed on attached bacteria and ensures that only ingested bacteria are counted rather than bacteria lying on the cell surface (Butler \& Rogerson 1997).

In high Arctic marine waters heterotrophic nanoflagellates had grazing rates ranging between 3 and 64 bacteria cell ${ }^{-1} \mathrm{~h}^{-1}$ (Laurion et al. 1995), which are comparable to rates reported elsewhere in marine environments (Weisse \& Scheffel-Moser 1991). Antarctic heterotrophic dinoflagellates have reported ingestion rates of 17.3 to $109.6 \mathrm{pg} \mathrm{C}$ cell ${ }^{-1} \mathrm{~h}^{-1}$ depending on species (Archer et al. 1996). These rates are low compared to those seen in lower latitudes. The grazing rates of amoebae in the current study ranged between 0.5 and 66.4 bacteria cell $\mathrm{l}^{-1} \mathrm{~h}^{-1}$ (equivalent to 0.3 and

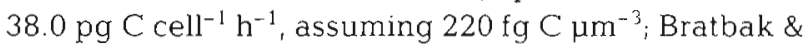
Dundas 1984). These rates are comparable to those found for temperate benthic amoebae when differences in prey size are considered; the Antarctic bacterium used in this study had a biovolume some 3 times larger than the bacterium used in previous temperate studies. Antarctic amoebae were well capable of feeding on a range of bacterial sizes, however, they may compensate for depressed feeding rates (related to sluggish locomotion rates) in the natural environments by selecting large cells which were common on seaweed surfaces. Temperate amoebae have been shown to consume between 0.2 and 194.7 bacteria $h^{-1}$, equivalent to $0.04-34.3 \mathrm{pg} \mathrm{C} \mathrm{cell}{ }^{-1} \mathrm{~h}^{-1}$ between 5 and $20^{\circ} \mathrm{C}$ (Butler \& Rogerson 1997), and some larger benthic amoebae, including reticulate forms, consumed between 10 and 1465 bacteria $h^{-1}$ at $18^{\circ} \mathrm{C}$ (Rogerson et al. 
1996). Although the range of prey used in the present experiments failed to achieve saturation in all cases, an experimental plateau was reached at $3.5 \times 10^{8}$ cells $l^{-1}$ at $2^{\circ} \mathrm{C}$. It is likely that this density was close to that promoting maximum consumption at other temperatures and that the rates reflect maxima expected in the field. It is difficult to correlate the densities used in the laboratory to conditions in the field; however, it is likely that amoebae experience local dense patches of prey on surfaces which reflect the densities (and high biomass values) used in the current study. Since it is likely that most amoebae are surface attached, the sea ice and suspended particles (marine snow) in Antarctic waters (Marchant et al. 1996) offer ideal habitats for coastal amoebae. Studies of amoebae in temperate waters have shown that they are common on bacterial rich surfaces (Rogerson 1991, Rogerson \& LaybournParry 1992a).

Surprisingly, there was no clear relationship between temperature and grazing rate (Table 2) which may be related to the way amoebae feed. The phagocytic response and locomotion rate of these slow moving cells is unlikely to be markedly affected by temperature. Within the protozoa as a whole, some studies have shown increased consumption rates with increasing temperature (e.g. Verity 1985) while others have shown no relationship (e.g. Laybourn \& Whymant 1980, Zwart \& Darbyshire 1992). Since temperature was unimportant in the present study it was possible to calculate mean specific uptake rates based on the 2 highest prey densities used. These were the densities promoting maximum growth and most likely to have general applicability in future ecological studies if it is assumed that amoebae inhabit bacteria rich surfaces. Platyamoeba australis gave a rate of 0.2 bacteria $h^{-1}$ $\mu \mathrm{m}^{-3}$ and isolate 5 a rate of 1.5 bacteria $\mathrm{h}^{-1} \mu \mathrm{m}^{-3}$. The difference in rate between these amoebae may reflect the faster rate of locomotion and hence increased prey contact in the eruptive vahlkampfiid, considered to be a member of the class Heterolobosea. Prey contact would have been less in the slower moving Platyamoeba of the class Lobosea (sensu Page 1988).

The present study is the first to present information of the growth and consumption potential of Antarctic marine amoebae. The results clearly show that amoebae remain active at in situ temperatures down to $-2^{\circ} \mathrm{C}$ and that their consumption rates are similar to those found in temperate regions. Although much of this ingested carbon is being used to maintain cell function, rather than being channeled into production, the study suggests that amoebae are important components of the grazing zooplankton, particularly since others have suggested that an important role of bactivorous amoebae may be their ability to crop bacteria from crevices and other regions inaccessible to other micrograzers (Rogerson \& Laybourn-Parry 1992b). Amoebae generally feed on surfaces (Rogerson unpubl.) and their ability to function at low tempertures indicates that they may be important in sea ice communities, where their presence has been noted (Garrison \& Buck 1989).

\section{LITERATURE CITED}

Archer SD, Leakey RJ, Burkill PH, Sleigh MA (1996) Microbial dynamics in coastal waters of East Antarctica: herbivory by heterotrophic dinoflagellates. Mar Ecol Prog Ser 139:239-255

Baldock BM, Baker JH (1980) The occurrence and growth rates of Polychaos fasciculatum, a rediscovered amoeba Protistologica 16:79-83

Baldock BM, Baker JH, Sleigh MA (1980) Laboratory growth rates of six species of freshwater Gymnamoebia. Oecologia 47:156-159

Baross JA, Morita RY (1978) Microbial life at low temperatures: ecological aspects. In: Kushner DJ (ed) Microbial life in extreme environments. Academic Press, London

Bjørnsen PK, Kuparinen J (1991) Growth and herbivory by heterotrophic dinoflagellates in the Southern ocean, studied by microcosm experiments. Mar Biol 109:394-405

Bratbak G, Dundas l (1984) Bacterial dry matter content and biomass estimations. Appl Environ Microbiol 48:755-757

Bunt JS (1970) Preliminary observations on the growth of a naked marine amoeba Bull Mar Sci 20:315-330

Butler H, Rogerson A (1996) Growth potential, production efficiency and annud production of marine benthic naked amoebae (gymnamorbae) inhabiting sediments of the Clyde Sea area, Scotland. Aquat Microb Ecol 10:123-129

Butler H, Rogerson A (1997) Consumption rates of six species of marine benthic naked amoebae (Gymnamoebia) from sediments in the Clyde Sea area. J Mar Biol Assoc UK $77: 989-997$

Caron DA, Lim EL, Miceli G, Waterbury JB, Valois FW (1991) Grazing and utilisation of chroococcoid cyanobacteria and heterotrophic bacteria by protozoa in laboratory cultures and a coastal plankton community. Mar Ecol Prog Ser 76 205-217

Cutler DW, Crump LM (1927) The qualitative and quantitative effects of food on the growth of a soil amoeba (Hartmannella hyalina). Br J Exp Biol 5:15.5-165

Epstein SS, Burkovsky IV, Shiaris MP (1992) Ciliate grazing on bacteria, flagellates and microalgae in a temperate zone sandy tidal flat: ingestion rates and food niche partitioning. J Exp Mar Biol Ecol 165:103-123

Fenchel T (1968) The ecology of marine microbenthos III. The reproductive potential of ciliates. Ophelia 5:123-136

Finlay BJ (1977) The dependence of reproductive rate on cell size and temperature in freshwater clliated protozoa. Oecologia 30:75-81

Garrison DL, Buck KR (1989) The biota of Antarctic pack ice in the Weddell Sea and Antarctic Peninsula regions. Polar Biol 10:211-219

Garrison DL, Buck KR (1991) Surface-layer sea ice assemblages in Antarctic pack ice during the austral spring: environmental conditions, primary production and community structure. Mar Ecol Prog Ser 71:161-172

Hara S, Tanoue E, Zenimoto M, Komaki Y, Takahashi E (1986) Morphology and distribution of heterotrophic protists along $75^{\circ}$ in the Southern Ocean. Mem Natl Inst Polar Res Spec Issue 40:69-80 
Heal OW (1967) Quantitative feeding studies on soil amoebae. In: Graff O, Satchell JE (eds) Progress in soil biology. North Holland Publishing Co, Amsterdam

Knox GA (1970) Antarctic marine ecosystems. In: Holdgate MW (ed) Antarctic ecology. Academic Press, London

Kottmeier ST, Sullivan CW (1990) Bacterial biomass and production in pack ice of Antarctic marginal ice edge zones Deep Sea Res 37:1311-1330

Laurion I, Demers S, Vezina AF (1995) The microbial food web associated with the ice algal assemblage: biomass and bacterivory of nanoflagellate protozoan in Resolute Passage (High Canadian Arctic). Mar Ecol Prog Ser 120 $77-87$

Laybourn J, Whymant L (1980) The effect of diet and temperature on reproductive rate of Arcella vulgaris Ehrenberg (Sarconina: Testacida). Oecologia 45:282-284

Marchant HJ, Watanabe K, Kawachi M (1996) Marine snow in the Antarctic sea-ice zone. Proc NIPR Symp Polar Biol 9: $75-83$

McManus GB, Fuhrman JA (1986) Bacteriovory in seawater studied with the use of inert fluorescent particles. Limnol Oceanogr 36:613-617

Nygaard K, Hessen DO (1990) Use of ${ }^{14} \mathrm{C}$ protein-labeled bacteria for estimating clearance rates by heterotrophic and mixotrophic flagellates. Mar Ecol Prog Ser 68:7-14

Pace DM, Frost BL (1952) Effects of ethyl alcohol on growth and respiration of Pelomyxa carolinensis. Biol Bull Mar Biol Lab Woods Hole 103:97-103

Page FC (1983) Marine Gymnamoebae. Institute of Terrestrial Ecology, Culture Collection of Algae and Protozoa, Cambridge, England

Page FC (1988) A new key to freshwater and soil gymnamoebae. Freshwater Biological Association, Ambleside, England

Patterson DJ (1994) Protozoa: evolution and systematics. In: Hausmann K, Hulsmann N (eds) Progress in protozoology, $1-14$. Proceedings of the IX International Congress of Protozoology, Berlin 1993. Gustav Fisher Verlag, Stuttgart

Rogerson A (1980) Generation times and reproductive rates of Amoeba proteus (Leidy) as influenced by temperature and food concentration. Can J Zool 58:543-548

Editorial responsibility: Diane Stoecker (Contributing Editor), Cambridge, Maryland, USA
Rogerson A (1991) On the abundance of marine naked amoebae on the surface of five species of macroalgae. FEMS Microbiol Ecol 85:301-312

Rogerson A, Berger $J$ (1981) Effect of crude oil and petroleum-degrading micro-organisms on the growth of freshwater and soll protozoa. J Gen Microbiol 124 53-59

Rogerson A, Laybourn-Parry J (1992a) The abundance of marine naked amoebae in the water column of the Clyde Estuary. Estuar Coast Shelf Sci 34:187-196

Rogerson A, Laybourn.-Parry J (1992b) Aggregate dwelling protozooplankton communities in estuaries. Arch Hydrobiol 125:411-422

Rogerson A, Laybourn-Parry J (1992c) Bacterioplankton abundance and production in the Clyde estuary, Scotland. Arch Hydrobiol 126:1-14

Rogerson A. Polne-Fuller M. Gibor A (1992) Lectin binding sites in marine amoebae. Arch Protistenkd (German) 141: $3-11$

Rogerson A, Hannah F, Gothe G (1996) The grazing potential of some unusual marine benthic amoebae feeding on bacteria. Eur J Protistol 32:271.-279

Sherr BF, Sherr EB, Bcrman T (1983) Grazing, growth and ammonium excretion rates of a heterotrophic microflagellate fed with four species of bacteria. Appl Environ Microbiol 45:1196-1201

Sherr EB, Sherr BF, Fallon RD (1987) Use of monodispersed, fluorescently labelled bacteria to estimate in situ protozoan bacterivory. Appl Environ Microbiol 53:958-965

Tobiesen A (1991) Growth rates of Heterophrys marina (Heliozoa) on Chrysochromulina polylepis (Prymnesiophyceae). Ophelia 33:205-212

Verity PG (1985) Grazing, respiration, excretion and growth rates of tintinnids. Limnol Oceanogr 30:1268-1282

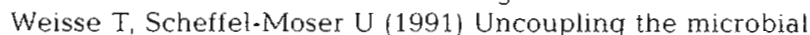
loop: growth and grazing rates of bacteria and heterotrophic nanoflagellates in the North Atlantic. Mar Ecol Prog Ser 71:195-205

Zwart KB, Darbyshire J (1992) Growth and nitrogenous excretion of a common soil flagellate Spumella sp., a laboratory experiment. J Soil Sci 43:145-14

Submitted: May 7, 1997; Accepted: October 28, 1997 Proofs received from author(s): December 8, 1997 